\title{
CAPITAL MARKET REACTION TO ANNOUNCEMENTS THE FIRST CASE OF CORONAVIRUS
}

\author{
Tiara Putri Nadiwa*1, Irni Yunita ${ }^{2}$ \\ Universitas Telkom, Indonesia*12 \\ tiara.nadiwa@gmail.com¹ , irniyunita81@gmail.com²
}

\begin{abstract}
The more important the role of the stock exchange in economic activity, the more sensitive the stock exchange is to various surrounding events, whether they are directly related to economic issues or not. The announcement of the first case of the coronavirus in Indonesia is one of the events that have the potential to affect market behavior. This study aims to analyze the reaction of the capital market to the announcement of the first case of the coronavirus in Indonesia. This study used an event study approach with measurements seen from differences in abnormal returns and trading volume activity before and after the event. The research sample was 45 companies selected by the purposive sampling technique. Data analysis used paired sample t-test on normally distributed data and Wilcoxon test on data not normally distributed. The results showed that there was no difference in abnormal returns and trading volume activity before and after the announcement of the first case of the coronavirus in Indonesia. This study concludes that events do not contain significant information that can influence investors' decisions in the capital market.
\end{abstract}

Keywords: Abnormal Return; Coronavirus; Event Study; LQ45 Index; Trading Volume Activity

\section{INTRODUCTION}

The capital market as a market is generally a meeting place between buyers and sellers. The capital market is a meeting between parties who have excess funds and parties who need funds by trading securities (Tandelilin, 2017). Price movements in the capital market can be influenced by several economic and non-economic factors. Although not directly related to the dynamics that occur in the capital market, the influence of the non-economic environment cannot be separated from capital market activities. What is important for the capital market is the role of information. Investors in making their investment decisions will pay close attention to the content of information that can come from various events (Chang et al., 2016).

Entering early March, to be precise on March 2, 2020, President Joko Widodo announced that two Indonesian citizens (WNI) had contracted the coronavirus. Both were infected with Japanese citizens, while a team from the Ministry of Health immediately searched (Ihsanuddin, 2020). Previously, the emergence of the coronavirus was first detected in China in early December 2019. Several patients arrived at the hospital in Wuhan with symptoms of unknown illness (Welle, 2020). The movement of the LQ45 Index from 24 February 2020 to 9 March 2020, which is 5 days before the event, the day the event occurred on 2 March 2020, and 5 days after the event occurred can be seen in Figure 1. 


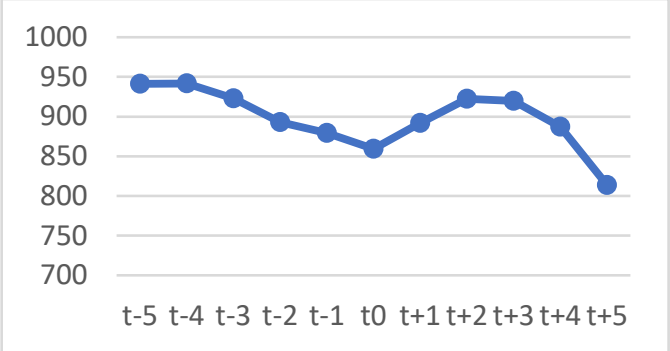

Figure 1. The Movement of the LQ45 Index in the Research Period Source: Yahoo Finance (2020)

After the announcement of the first case of the coronavirus in Indonesia on Monday afternoon, March 2, 2020, 45 leading stocks or the LQ45 Index fell 20.2 points or 2.3 percent to 859.33 (Antara, 2020). A total of 10 stocks on the LQ45 Index stock list corrected more than 3 percent. The decline in stock prices caused the Composite Stock Price Index (IHSG) to drop 1 percent. The pressure on the domestic stock market was triggered by a statement by President Joko Widodo who confirmed that the coronavirus had entered Indonesia (Saragih, 2020).

The efficient market hypothesis discusses the relationship between information and stock prices. The effect of information that causes market reactions can be measured using abnormal returns and the movement of trading volume activity due to the influence of information can be measured by trading volume activity. The purpose of this study was to determine whether there were significant differences in abnormal returns and trading volume activity before and after the announcement of the first case of the coronavirus in Indonesia.

A capital market is a place where various parties, especially companies sell stocks (stock) and bonds (bonds) with the aim of the sale proceeds will be used as additional funds or to strengthen the company's capital (Fahmi, 2012). According to Tandelilin (2017), the LQ45 index consists of 45 stocks on the Indonesia Stock Exchange with large market capitalization and high liquidity and has passed the selection according to several selection criteria. An efficient market is a market in which the price of traded securities reflects all available information. In this case, the available information may include information available both in the past (for example, the company's last year's profit), as well as current information (for example the planned dividend increase this year), as well as information that is a rational opinion or opinion circulating in the market. which can affect price changes (Tandelilin, 2017).

According to Hartono (2017), an event study is a study that studies market reactions to an event whose information is published as an announcement. Event studies can also be used to test the information content of an event or announcement. If an event or announcement contains information, the market will react when the announcement is received by the market. According to Hartono (2017), abnormal return occurs due to an excess of actual return against normal return which is the return expected by investors. Normal return is the expected return (the return expected by investors). Thus, abnormal return is the difference between the actual return that occurs and the expected return. Trading volume activity is the ratio between the number of shares traded at a certain time to the number of shares outstanding at a certain time (Husnan, 2009).

The research hypothesis can be formulated as follows:

$\mathrm{H} 1$ : There is a significant difference in the abnormal return of companies listed in the LQ45 Index for the period February - July 2020 before and after the announcement of the first case of the coronavirus in Indonesia. 
$\mathrm{H} 2$ : There is a significant difference in the trading volume activity of the shares of companies listed in the LQ45 Index for the period February - July 2020 before and after the announcement of the first case of the coronavirus in Indonesia.

\section{METHODS}

The research method used is quantitative. In this study, the event study market efficiency testing method was used with operational variables abnormal return (AR) and trading volume activity (TVA). The model used to estimate the expected return on abnormal return is a market-adjusted model so there is no need to use the estimation period to form an estimation model because the estimated return is the same as the market return.

The observation period of this study was 5 trading days before and 5 trading days after the event. The population in this study were companies listed in the LQ45 Index for the period February - July 2020. The samples were determined using nonprobability sampling technique with purposive sampling method, namely sampling using certain criteria. The criteria for the shares of the companies sampled were that the company was consistently listed in the LQ45 Index group for the period February - July 2020 and did not take corporate actions such as announcing dividends, profits, rights issues, stock split, etc. during the study period. The aim is to prevent a confounding effect, namely market reactions to other events that are close to the events being studied.

The data used in this research is secondary data. The data collected include information from event publications, company data on the LQ45 Index, daily stock prices, daily $\mathrm{JCl}$ (close price), daily share volume, and the number of shares outstanding. The analysis technique used to test the hypothesis in this study is a different test, but previously the data normality test was carried out to determine whether the data used was normally distributed or not. If the data is normally distributed, the paired sample ttest is used with a significance level of $5 \%$ to test the hypothesis, but if the data is not normally distributed, the Wilcoxon test is used as hypothesis testing.

\section{Descriptive Statistics}

\section{RESULTS AND DISCUSSION}

Table 1. Descriptive Statistics Results

\begin{tabular}{ccccc}
\hline & Minimum & Maximum & Mean & Std. Deviation \\
\hline AR before & $-0,05697$ & 0,04149 & $-0,00504$ & 0,0219033744 \\
AR After & $-0,02245$ & 0,06057 & $-0,00498$ & 0,0256396078 \\
TVA before & 0,00036 & 0,00805 & 0,00161 & 0,0015081198 \\
TVA after & 0,0003 & 0,0085322 & 0,001605 & 0,0015504566 \\
\hline
\end{tabular}

Source: Processed Data (2020)

Based on table 1, the average abnormal return before the event was $-0.504 \%$, while the average abnormal return after the event was $-0.498 \%$. The average trading volume before the event was $0.161 \%$, while the average trading volume after the event was $0.1605 \%$. The minimum abnormal return value before the event is $-5.697 \%$, while the minimum abnormal return value after the event is $-2.245 \%$. The minimum trading volume activity value before the event is $0.036 \%$, while the minimum trading volume after the event is $0.03 \%$. The maximum abnormal return value before the event was $4.129 \%$, while the maximum abnormal return value after the event was $6.057 \%$. The maximum trading volume value before the event was $0.805 \%$, while the maximum trading volume after the event was $0.853 \%$. One method of normality test that can be done is the Kolmogorov-Smirnov test. 


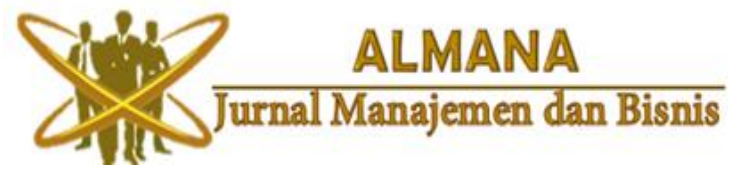

Table 2. Data Normality Test Results

\begin{tabular}{lccc}
\hline & \multicolumn{3}{c}{ Kolmogorov-Smirnov } \\
& Statistic & N & Sig. \\
\hline Abnormal Return before the event & 0,106 & 45 & 0,200 \\
Abnormal Return after the event & 0,108 & 45 & 0,200 \\
Trading Volume Activity before the event & 0,209 & 45 & 0,000 \\
Trading Volume Activity after the event & 0,181 & 45 & 0,001 \\
\hline
\end{tabular}

Source: Processed Data (2020)

Based on table 2, it can be seen that the significance value of the abnormal return before and after the event is greater than 0.05 , so the data is normally distributed. Then the test will be continued with a paired sample t-test. The significance value of trading volume activity before and after the event is less than 0.05 , so the data is not normally distributed. Then the test will be continued with the Wilcoxon test. Hypothesis testing using paired sample t-test (abnormal return) and Wilcoxon test (trading volume activity).

Table 3. The Results of Different Tests are the Average Abnormal Return Value (Paired Sample T-Test)

\begin{tabular}{|c|c|}
\hline & Paired Sample Correlations \\
\hline & Sig. \\
\hline Before - After & 0,168 \\
\hline
\end{tabular}

Table 4. The Results of Different Tests Are the Average Trading Volume Activity Value (Wilcoxon Signed Rank Test)

\begin{tabular}{cc}
\hline & After - Before \\
\hline$Z$ & $-0,559$ \\
Sig. (2-tailed) & 0,576 \\
\hline Source: Processed Data (2020)
\end{tabular}

From table 3 above, the results of statistical tests using the paired sample t-test show that there is no significant difference in abnormal returns before and after the event as indicated by the Sig value. $0.168>0.05$. From table 4 above, the results of statistical tests using the Wilcoxon test show that there is no significant difference in trading volume activity before and after the event indicated by the Sig value. $0.576>0.05$.

This research is also almost the same as the research conducted by Sukmaningrum et al. (2019) that there is no significant difference in abnormal returns and trading volume activity before and after the 2017 DKI Jakarta Governor's appointment because the information has been circulating before the event occurs.

There was no difference in abnormal returns and trading volume activity before and after the announcement of the first case of the coronavirus in Indonesia, which was conveyed by President Joko Widodo on March 2, 2020, was neutral, because other countries, especially in the Asian region, had announced cases in advance. the first coronavirus before the incident occurred in Indonesia. Therefore, investors do not want to rush in making decisions and tend to wait and see waiting for government policies. 


\section{CONCLUSION}

Based on the results of research and discussion, it can be concluded that the announcement of the first case of the coronavirus in Indonesia did not have a significant difference between abnormal return and trading volume activity before and after the announcement of the first case of coronavirus in Indonesia in companies listed in the LQ45 Index for the February period - July 2020. This study concludes that events do not contain significant information that can affect investors' decisions in the capital market.

\section{REFERENCES}

Antara. (2020). IHSG Melemah 1,68 Persen Pasca Indonesia Positif Virus Corona. Retrieved September 12, 2020, website: (https://bisnis.tempo.co/read/1314535/ihsg-melemah-168-persen-pascaindonesia-positif-virus-corona).

Chang, Ching-Yun, Yue Zhang, Zhiyang Teng, Zahn Bozanic, and Bin Ke. (2016). Measuring the Information Content of Financial News. p. 3216-3225 in ac/web.org.

Fahmi, I. (2012). Pengantar Pasar Modal. Bandung: Alfabeta.

Hartono, Jogiyanto. (2017). Teori Portofolio Dan Analisis Investasi. Yogyakarta: BPFE.

Husnan, S. (2009). Dasar-Dasar Teori Portofolio Dan Analisis Investasi. Yogyakarta: UPP AMP YKPN.

Insanuddin. (2020). Fakta Lengkap Kasus Pertama Virus Corona di Indonesia. Retrieved September 12, 2020, from Kompas.com website: https://nasional.kompas.com/read/2020/03/03/06314981/fakta-lengkap-kasuspertama-virus-corona-di-indonesia?page=all

Saragih, Houtmand P. (2020). Virus Corona Masuk RI, 10 Saham LQ45 Anjlok Lebih Dari 3\%. Retrieved September 12, 2020, wesbite: (https://www.cnbcindonesia.com/market/20200302130049-17-141700/viruscorona-masuk-ri-10-saham-lq45-anjlok-lebih-dari-3).

Sukmaningrum, P. S., M. Madyan, and A. Hendratmi. (2019). "Reaksi Pasar Saham Yang Terdaftar Dalam Jakarta Islamic Index (JII) Terhadap Pengumuman Penetapan Gubernur DKI Jakarta Tahun 2017." Jurnal Ekonomi Dan Bisnis Islam (JEBIS). 5(1):1-14.

Tandelilin. (2017). Pasar Modal: Manajemen Portofolio Dan Investasi. Yogyakarta: PT Kanisius.

Welle, Deutsche. (2020). Timeline Penyebaran Virus Corona Di Dunia. Retrieved September 12, 2020, from Detik.com website: (https://news.detik.com/dw/d4948386/timeline-penyebaran-virus-corona-di-dunia).

Yahoo Finance. (2020). LQ45 Historical Data. Retrieved September 12, 2020 , website: (https://finance.yahoo.com/quote/\%5EJKLQ45/history?p=\%5EJKLQ45). 